\title{
Does Birth Spacing Affect Personality?
}

\author{
Bart Golsteyn \\ Cécile A. J. Magnée
}

Working Paper

2017-023

$03 / 2017$

PST MUMANCAPTALAND

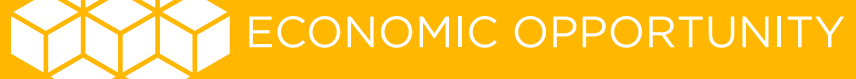

WDI GLOBAL WORKNG GPOUY
The University of Chicago 1126 E. 59th Street Box 107 Chicago IL 60637 


\title{
Does Birth Spacing Affect Personality?*
}

\author{
Bart H. H. Golsteyn ${ }^{* *}$, Cécile A. J. Magnée ${ }^{* * *}$
}

\begin{abstract}
This paper studies the causal effect of birth spacing (i.e., the age difference between siblings) on personality traits. We use longitudinal data from a large British cohort which has been followed from birth until age 42. Following earlier studies, we employ miscarriages between the first and second child as an instrument for birth spacing. The results show that a larger age gap between siblings negatively affects personality traits of the youngest child in two-child households. This result sheds a first light on the causal effects of birth spacing on personality traits.
\end{abstract}

Keywords: birth spacing, family structure, personality traits

JEL: J12, J13, J24

\footnotetext{
* The authors thank Lex Borghans, the editor Martin Kocher, an anonymous referee, and seminar participants at Maastricht University for their valuable comments. This research is funded by a grant from the Graduate School of Business and Economics at Maastricht University and by a VIDI grant from the Netherlands Organization for Scientific Research (NWO).

** Corresponding author. Department of Economics, Maastricht University, P.O. Box 616, 6200 MD, Maastricht, the Netherlands. Phone nr: +31 43388 3736. b.golsteyn@,maastrichtuniversity.nl.

${ }^{* * *}$ Department of Economics, Maastricht University, P.O. Box 616, 6200 MD, Maastricht, the Netherlands. Phone nr: +31 43388 3736. c.magnee@,maastrichtuniversity.nl.
} 


\section{Introduction}

Family structures have important effects on individuals' lives. It has been documented in economics, psychology and medicine that the number of children and the order of the child within the family affect vital outcomes in life such as educational attainment, intelligence and health (see, e.g., Rohrer et al. 2015, Bjerkedal et al. 2007, Hotz and Pantano 2015, Black et al. 2007, and Barclay 2015).

This paper investigates whether the age difference between siblings affects personality traits. Personality traits are crucial for success in life (see, e.g., Borghans et al. 2016). The birth gap can be expected to affect personality traits for several reasons. When the birth gap is small, siblings compete for similar parental resources around the same time (e.g., help with learning how to ride a bike, payment of school fees, help with homework). On the other hand, a small birth gap implies that when parents help one child, the other may be more able to learn from this as well, and that the siblings may be more able to play with each other and learn from each other. The birth gap may affect personality traits such as competitiveness, neuroticism, extraversion, social skills, selfesteem, locus of control, etc. It may also affect behavioral problems in school and disorganized behavior. Because of the contrasting mechanisms, the signs of the effects of the birth gap on personality traits are difficult to predict.

We use the 1970 British Cohort Study, a longitudinal data base consisting of approximately 17,000 children born in the UK in one week of April 1970. These children have been followed in 10 surveys from birth (parental survey) up to an age of 42 . The data contain the following personality traits of the children at age 10: Rutter behavioral problems, self-esteem, locus of control, disorganized behavior, anti-social behavior, 
neuroticism, and introversion. The data also contain information about the amount of siblings and their year of birth, and about the pregnancy and health of the child's mother. Because we only have information about miscarriages (i.e., our instrumental variable: see below) before the birth of the child that is followed in the survey, we can only estimate the effects of birth spacing on the personality of the youngest child. We furthermore focus on two-child households to abstract from analytical complexities of several age differences between siblings within the family (e.g., in three child families: youngest versus the oldest child, youngest versus the middle child), family size and birth order effects. In addition, we study the effects on male and female children separately.

An analytical challenge is that the age gap between children within a household is endogenous. Various confounding factors may relate both to birth spacing and to the personality of the youngest child. For instance, the personality of parents may be related to the choice to wait longer to have a second child, and to the personality of the second child. This implies that in order to study the causal relationship between birth spacing and personality, we need exogenous variation in birth spacing. In line with Buckles and Munnich (2012) who study the effect of birth spacing on achievement test scores, we use miscarriages between the first and second child as an instrument for birth spacing. The assumptions underlying this method are that (1) women who miscarry between their first and second child on average have a much larger age difference between the children, and (2) that miscarrying occurs at random.

We carefully inspect the assumptions underlying our method. With respect to the first assumption, we show that miscarriages indeed highly correlate with birth spacing. The F-statistics in the first stage regressions show that miscarriage is a strong instrument 
for birth spacing. Concerning the second assumption, we show that miscarriages do not correlate with several observables: smoking behavior of the mother during pregnancy, age of the mother at the birth of her first child, feelings of depression, and social class. However, we do find that mothers who miscarried between their first and second child are under closer surveillance by the hospital in their pregnancy of the youngest child. They more often receive antenatal care. We control for the use of antenatal care in our regressions. More importantly, we also find that women who miscarry between their first and second child were more likely to also have miscarried before their first child. This indicates that there may be a genetic or behavioral component to miscarrying. We therefore control for the number of miscarriages that occurred before the first child in our regressions. Conditional on these controls, miscarriages arguably occur at random, implying that we can use them as exogenous shocks. We also show that the results remain similar when we do and do not control for these variables.

An important additional challenge is that our instrument may be related to children's outcomes via different variables than the birth gap. The most obvious candidates are maternal mental and physical wellbeing. However, the literature overview given by Buckles and Munnich (2012) reveals that it is unlikely that our instrument is related to maternal mental or physical wellbeing.

The main result of our analysis is that a larger age gap between siblings negatively affects personality traits. Specifically, a larger birth gap leads to more disorganized behavior, more neuroticism, and more introversion. For small gap ranges (gaps of less than 4 years or a gap of 2 or 3 years), we find that a larger gap leads to less self-esteem, more introversion and more anti-social behavior. Separating the results for 
boys and girls, girls become more neurotic due to a larger birth gap, while for smaller gap ranges, they become more anti-social and more introverted. Boys become more neurotic for large gap ranges and more disorganized for small gap ranges.

Our study contributes to a large literature on the effects of family structure on important life outcomes. One part of this literature focuses on the effects of birth order on personality and intelligence. Rohrer et al. (2015) and Bleske-Rechek and Kelley (2014) find no effect of birth order on personality. However, Roher at al. (2015) do find that intelligence decreases with a higher birth order. This last result has been confirmed by Bjerkedal et al. (2007), Hotz and Pantano (2015), Black et al. (2007) and Barclay (2015), and challenged by Kanazawa (2012). Salmon et al. (2016) find that birth order has a moderate (positive) effect on pro-social behavior. The findings on the effects of birth order on personality thus remain inconclusive.

In a recent meta-study in pediatrics, the effects of birth spacing on one facet of personality were taken into consideration. Conde-Agudelo et al. (2016) analyze the noncausal relationships of the birth gap and autism. Their conclusion is that short birth intervals are associated with an increased risk of autism spectrum disorder. Our contribution to this literature is that we study the effects on several facets of personality, and that we do take the endogeneity of the birth gap into consideration.

There have been few papers which have studied causal effects of birth spacing and to our knowledge the causal relationship between birth spacing and personality has not been studied before. Buckles and Munnich (2012) use miscarriages as an instrument for birth spacing, and find no effect of the birth gap on the PIAT achievement test scores for the youngest child in a sample of US children. Our study shows negative effects of a 
larger birth gap on personality. Because personality is positively related to educational outcomes, this appears to be inconsistent with Buckles and Munnich's research. However, a negative effect on personality does not necessarily imply that educational outcomes are also negatively affected by the birth gap. The reason for this is that other factors related to education may also be affected by the birth gap. In an extension of the analysis, we investigate the causal relationship between the birth gap and a large vector of achievement tests and educational outcomes. We find no robust significant effects of the birth gap on achievement test scores which is in line with the findings in Buckles and Munnich's article. In some specifications, there is a significant negative effect on educational outcomes but in most specifications and for most educational attainment variables there are no effects. The results are therefore inconclusive on the relationship between birth gaps and educational outcomes.

The paper proceeds as follows. Section 2 describes the data. Section 3 discusses the empirical strategy. Section 4 reports the results. Section 5 gives the conclusions.

\section{Data}

We use the British Cohort Study (BCS70) which follows a cohort of approximately 17,000 babies who were born in the same week in April, 1970 in England, Scotland and Wales since birth. These individuals have been followed over a time span of 42 years in 10 surveys, namely at the ages of $2,5,10,16,21,26,29,34,38$, and 42 .

Important for our paper is that the dataset contains information about whether the mother had a miscarriage before conceiving the second child, and that at the age of 10 
several questions about personality traits were asked to the child itself and to its mother and its teacher.

There is considerable panel attrition over the years (see table A1). At age 10, still around $87 \%$ of the sample remains. The attrition is not related to the main variables of our analyses (personality traits, birth spacing, miscarriages), so we conclude that it is unlikely that it is important for our results.

\section{Sample}

We restrict our sample to families with two children, whose first surviving child was born before 1970 and the second surviving child in April 1970. We only have data on the child born in 1970 so our analysis focuses on the effects for the youngest child in the household. We exclude families with siblings born after the second child. We also exclude all twins (120 subjects) from the sample, since in this case there are no miscarriages possible between the first and second child. As a result, the sample reduces from 17,196 to 4,114 children. Table 1 gives an overview of the descriptive statistics of all the variables.

\section{Birth spacing}

We define birth spacing as the difference in years between the two siblings in the household. The mean birth gap is 3.5 years (see table 1), which is remarkably similar to the reported gap in the sample of Buckles and Munnich (2012) (3.4 years) and to the 1988 Natality Detail files (3.4 years). 
An important caveat in our study is that we only have information on birth spacing in years which is crude relative to the measure used for instance by Buckles and Munnich (2012) who report the spacing in months. On the positive side, our data contain more observations of miscarriages than theirs: 424 relative to 291 in their sample. Having enough observations is crucial for our analysis since miscarriages are relatively rare.

We study the linear relationship between birth spacing and personality. However, it may be that there are important non-linearities in the relationship, e.g. that there is an optimal amount of birth spacing. We show separate regressions with varying restrictions on the range of the birth gap. Figure 1 shows the cumulative distribution of the birth gap. We restrict the sample to a gap of 15 years (the $99^{\text {th }}$ percentile) in our baseline estimate in order to exclude outliers. In the robustness checks, we show estimates for the full sample, a restriction on a gap smaller than 7 years (the $90^{\text {th }}$ percentile), a gap smaller than 5 years, smaller than 4 years, and a gap of 2 or 3 years.

\section{Miscarriage}

Information about the survival of children born before 1970 was provided in different categories, namely 'alive in April 1970,' 'died under 7 days,' 'died 7 days and over,' 'stillbirth,' 'miscarriage,' 'ectopic,' and 'hydatidiform mole.' We use two definitions of miscarriages. In our broad definition (the baseline analyses), we use the number of occurrences in all categories of this variable as an instrument (excluding 'alive in April 1970'). In our narrow definition we only use the number of miscarriages between the oldest and youngest child as an instrument. The results are qualitatively the same under 
both definitions. In our sample, $7.8 \%$ of the women were aware that they experienced a miscarriage between the first and second born child. This likelihood of miscarriage is similar to that found in other studies. For instance, Buckles and Munnich (2012) report that $5.8 \%$ of the women miscarried. Tables A2 and A3 shows the frequency table of miscarrying in the broad and narrow definition respectively.

\section{Personality traits}

The following personality traits are measured in the data: Rutter behavioral problems, self-esteem, locus of control, disorganized, anti-social behavior, neuroticism and introversion.

Rutter scores are answered by the mother. A full list of questions underlying the Rutter score is displayed in Table A4. A higher Rutter score indicates more negative overall behavior of the child. We use the principle component of the items standardized to a mean of zero and standard deviation of one in order to be able to compare the coefficients across the variables.

Children were asked questions about their self-esteem and about their locus of control. An overview of the questions is provided in Tables A5 (self-esteem) and A6 (locus of control). A higher score on the self-esteem scale implies a higher self-esteem of the child. A higher score on the locus of control scale implies a more internal locus of control.

Questions about disorganized, anti-social, neurotic and introverted behavior are answered by the teacher of the child. The questions about personality traits of the child were part of a bigger survey on the child's behavior. Table A7 shows the questions per 
personality trait. A higher score on the variables indicates respectively more disorganized, asocial, neurotic and introverted behavior of the child.

\section{Control variables}

We control for several important variables in our regressions. By comparing the estimates before and after controlling, we can get a sense of the extent to which our instrument indeed provides exogenous variation. Next to this, controlling for important characteristics which are related to the personality of children can help to increase the efficiency of the estimates.

Most of the controls are characteristics of the mother: e.g., the mother's age at the delivery of the first born, ${ }^{1}$ her smoking behavior during pregnancy, whether she is married or not, and her and her partner's socio-economic class. The age of the mother and her smoking behavior are important controls as these might be related to our instrument. We exclude mothers who were younger than 16 when they had their first child (seventeen in total). On average, women in this sample had their first child at age 23 (see Table 1). Figure A1 shows that there is a large variation in the distribution of the mothers' age when they had her first child. Around $43 \%$ of the women smoked during pregnancy. For current standards, this is a very high percentage. Table A8 gives more information about the amount of cigarettes smoked by these women. Around $97 \%$ of the women were married in 1970 (see Table 1). Tables A9 and A10 show statistics on the social class of the father and the mother. Marriage and social class are important controls as they may influence the upbringing of the child.

\footnotetext{
${ }^{1}$ It is important to control for the age at delivery of the first born and not of the youngest child since the age of the youngest child is related to the instrument.
} 
In our most elaborate estimations, we also control for various other factors. We control for these variables in a separate estimation as the number of observations related to these variables is lower than for the other controls (see Table 1). We control for the stability of the marriage: Table 1 shows that $89 \%$ of the children lived with the same parents since birth. We also control for the mother's psychological health at age 5 of the child, for a number of variables related to the mother's attitude toward child rearing and toward other views about life (see tables A11 and A12 for the lists of questions). These attitudes may be related to personality traits. Controlling for these variables may therefore reduce standard errors of our regressions. We control also for antenatal care (Table 1 shows that around $16 \%$ of the women used antenatal care), and the amount of miscarriages before the oldest child because these variables are related to our instrument as explained below (see Table A13 for the frequency of miscarrying before the oldest child).

\section{Empirical Strategy}

Birth spacing is endogenous which implies that we cannot rely on OLS regressions of personality traits on the birth gap. ${ }^{2}$ In order to study the causal relationship between birth spacing and personality, we need exogenous variation in birth spacing. Following Buckles and Munnich (2012), we employ an instrumental variables approach exploiting miscarriages between the first and second child as an exogenous source of variation in the birth gap. The assumptions underlying this method are that (1) women who miscarry between their first and second child on average have a larger age difference between the children, and (2) that miscarrying occurs at random. Below we discuss these assumptions.

\footnotetext{
${ }^{2}$ The appendix table A14 reports the OLS estimations.
} 
First stage estimations

In order to investigate whether miscarriages can be used as an instrument for the birth gap, we first show histograms of the birth gaps for mother who did and who did not miscarry. Figure 2 clearly shows that the distribution of the birth gap of mothers who miscarried lies more to the right than for the non-miscarrying mothers.

First stage regressions in Table 2 confirm that on average, miscarriages lead to a larger birth gap. The table reports regressions of the relationship for three variants of the birth gap variable, including and excluding controls. It is evident that miscarriage is a strong predictor of the birth gap (F-test $>10)$ in all variants of the regressions.

Interestingly, the table also shows that the birth gap appears to be endogenous as it is related to various controls, e.g. mother's age at delivery of the first child, smoking, social class, etc. This supports our choice to show IV regressions instead of focusing on correlations.

\section{Exogeneity assumption}

The second condition for our instrument to be valid is that miscarriages occur at random. Buckles and Munnich (2012) mention that chromosomal abnormality in the fetus is the most common reason for miscarriages. This abnormality is usually random and not associated with a higher risk of miscarrying in a next pregnancy. However, there may be other unobserved reasons for miscarrying. In order to get a sense of the validity of the assumption that miscarrying occurs at random, we show in Table 3 that miscarriages do not correlate with the observables in our data: e.g. smoking behavior of the mother during 
pregnancy, age of the mother, feelings of depression, and social class. The table shows that mothers who miscarried between their first and second child more often make use of antenatal care. This is logical because after a miscarriage, both women and their physicians may want to monitor the pregnancy more closely. We will control for the use of antenatal care (and for the other observables) in our regressions.

Although the main determinant of miscarrying (chromosomal abnormality in the fetus) may occur at random and not give a higher risk in the next pregnancy, the table reveals that women who miscarry between their first and second child were more likely to also have miscarried before their first child. This implies that there may be a genetic or behavioral component to miscarrying. We therefore control for miscarriages that happened before the first child in our regressions. Conditional on these controls, miscarriages arguably occur at random, implying that we can use them as exogenous shocks.

A related issue is that miscarriages may affect the outcomes we study through other channels than the birth gap. The most obvious channel may be that mothers suffer mentally or physically after a miscarriage. The literature discussed by Buckles and Munnich (2012) has concluded however that symptoms of depression or anxiety typically disappear within one year after a miscarriage. Moreover, women who have a healthy pregnancy after the miscarriage (as is the case in our analysis) appear to be less likely to suffer from depression. Miscarriages furthermore do not appear to affect attachment to the next born child, and mothers who miscarry after the first born child are at lower risk of delivering prematurely than those who had not previously given birth. We conclude 
from these earlier studies that it is unlikely that reduced maternal mental or physical wellbeing can explain our findings.

Buckles and Munnich (2012) present other interesting points with respect to the identification strategy. One issue is that a miscarriage is both related to a change in birth spacing and to a change in parental age. Therefore, the effect of spacing cannot be identified independent of parental age. However, from a policy perspective, the combined effect of spacing and parental age is of interest since any policy which increases spacing will also increase parental age. A second point is that miscarriages may be underreported. Assuming this underreporting is random, our estimates are attenuated, and hence present lower bounds.

\section{Results}

Table 4 shows the main result of our analysis: a larger birth gap has a significant negative effect on personality traits: disorganized behavior and neuroticism. Importantly, the relationships are robust to the inclusion of the controls describes above. The results show that if the age gap between siblings increases with one year, disorganized behavior increases with approximately 0.11 standard deviations and neuroticism with 0.15 standard deviations.

Table 5 reveals that when we reduce the gap range, the coefficients increase dramatically in size. For very small gap ranges, the size of the effect on disorganized behavior and that on neuroticism increase to around 0.46 and 0.57 standard deviations respectively. Note, however, that due to smaller sample sizes, these effects are no longer significant. At very small ranges, we find significant and very large effects on almost all 
other traits: self-esteem (0.80), asocial behavior (0.79), and introversion (1.08). The only trait which does not seem to be affected are Rutter behavioral problems.

Table 6 shows that if we use the narrow definition of miscarriages, results remain similar although less significant at small ranges.

Tables 7 and 8 separate the results for boys and girls. Sample sizes reduce with around 50\% so many significant results are no longer significant. Nevertheless, it appears that both boys and girls become more neurotic when faced with a larger birth gap. Boys additionally become more disorganized while girls become more anti-social and introverted.

\section{Birth gap and educational outcomes}

Our study shows negative effects of a larger birth gap on personality, which in turn suggests negative effects on outcomes related to personality such as education. In light of the earlier findings of zero effects of the birth gap on achievement test scores (Buckles and Munnich 2012), an important further question is how to interpret our results relative to their results. Are larger birth gaps good or bad for children's educational attainment?

Theoretically, it is important to note that our findings are not necessarily inconsistent with the findings of these authors because birth gaps may affect a large array of variables which in turn affect educational outcomes. So even if the birth gap negatively affects personality and personality is positively related to education, it may still be that the birth gap does not affect education.

We investigate the effects of the birth gap on a large vector of achievement tests and educational outcomes: see Table 9. We find no robust significant effects of a larger 
birth gap on any achievement test which is in line with Buckles and Munnich's result. The results show no effects or in certain specifications significant negative effects on other education outcomes. The results are therefore inconclusive on the relationship between birth gaps and educational outcomes.

\section{Conclusions and policy implications}

This paper shows that larger age gaps between siblings negatively affect personality traits of the youngest child in a two-child household. Specifically, a larger birth gap leads to more disorganized behavior, more neuroticism, and more introversion. For small gap ranges (gaps of less than 4 years or a gap of 2 or 3 years), we find that a larger gap leads to less self-esteem, more introversion and more anti-social behavior. Separating the results for boys and girls, girls become more neurotic when the birth gap is larger, while for smaller gap ranges, they become more anti-social and more introverted. Boys become more neurotic for large gap ranges and more disorganized for small gap ranges.

Although personality traits appear to be negatively affected by the birth gap, it remain unclear at this point whether the birth gap affects future success of children in education and the labor market. More research is needed on this relationship. If the government targets to improve personality traits as such, it can be interesting for policy makers to consider interventions to shorten birth gaps. Policy makers can intervene in many ways, from providing information or services to economic incentives or regulations. One type of intervention can for instance be to provide information about the negative effects of a larger birth space on personality of the second child through online campaigns or leaflets at gynecologists' waiting rooms. Another implementation of such 
an intervention was done in Sweden, where women receive more parental leave benefits when the gap between children was less than two years (see Petterson-Lidbom and Skogman Thoursie 2009). In this way, the maternal leave period is condensed, which is financially attractive for the government, as well as for the mother. Not only will she receive more money when she shortens the birth gap between two siblings, she may also be more able to re-enter the labor market sooner. This will result in lower depreciation of her skills and a higher likeliness to find a job that matches her skills, and thus receiving a higher income.

\section{References}

Conde-Agudelo, A., Rosas-Bermudez, A., Norton, M. (2016). Birth spacing and risk of autism and other neurodevelopmental disabilities: a systematic review. Pediatrics 137 (5): e20153482.

Barclay, K. (2015). A within-family analysis of birth order and intelligence using population conscription data on Swedish men. Intelligence 49, 134-143.

Bjerkedal, T., Kristensen, P., Skejeret, G., Brevik, J.I. (2007). Intelligence test scores and birth order among young Norwegian men (conscripts) analyzed within and between families. Intelligence 35 (6), 503-514.

Black, S., Devereux, P., Salvanes, K. (2007). Older and wiser? Birth order and IQ of young men. NBER working paper 13237.

Bleske-Rechek, A., Kelley, J. (2014). Birth order and personality: a within-family test using independent self-reports from both firstborn and later born siblings. Personality and Individual Differences 56, 15-18. 
Borghans, L., Golsteyn, B.H.H., Heckman, J.J., Humphries, J.E. (2016). What Grades and Achievement Tests Measure. Proceedings of the National Academy of Science, doi: 10.1073/pnas.1601135113.

Buckles, K., Munnich, E. (2012). Birth spacing and sibling outcomes. Journal of Human Resources 47 (3), 613-642.

Feinstein, L. (2000). The relative economic importance of academic, psychological and behavioural attributes developed on childhood. CEPDP, 443. Centre for Economic Performance, London School of Economics and Political Science, London, UK. Kanazawa, S. (2012). Intelligence, birth order and family size. Personality and Social Psychology Bulletin 38 (9), 1157-64.

Petterson-Lidbom, P., Skogman Thoursie, P. (2009). Does child spacing affect children's outcomes? Evidence from a Swedish reform. IFAU Working Paper 2009 (7).

Rohrer, J.M., Egloff, B., Schmuckle, S.C. (2015). Examining the effects of birth order on personality. Proceedings of the National Academy of Sciences of the United States of America 112 (46), 14224-14229.

Salmon, C., Cuthbertson, A. and Figueredo, A. (2016). The relationship between birth order and prosociality: an evolutionary perspective. Personality and Individual Differences 96, 18-22.

Hotz, V. J., Pantano, J. (2015). Strategic parenting, birth order, and school. Journal of Population Economics 28 (4), 911-936. 


\section{TABLES AND FIGURES}

\section{Table 1 Descriptive statistics}

\begin{tabular}{llll}
\hline & Obs. & Mean & St. Dev. \\
\hline Rutter behavioral difficulties & 2859 & 0 & 1 \\
Self-esteem & 2630 & 0 & 1 \\
Locus of control & 2589 & 0 & 1 \\
Disorganized & 2553 & 0 & 1 \\
Asocial & 2722 & 0 & 1 \\
Neuroticism & 2740 & 0 & 1 \\
Introversion & 2740 & 0 & 1 \\
& & & \\
Gap (in years) & 4113 & 3.508 & 2.393 \\
& & & \\
Number of miscarriages between first and second child (broad) & 4114 & 0.120 & 0.420 \\
Number of miscarriages before first child (broad) & 4114 & 0.130 & 0.422 \\
Number of miscarriages between first and second child (narrow) & 4114 & 0.095 & 0.378 \\
Number of miscarriages before first child (narrow) & 4114 & 0.088 & 0.351 \\
& & & \\
Gender (1=male) & 4114 & 0.523 & 0.500 \\
Mother's age at delivery of first child (in years) & 4097 & 22.987 & 3.848 \\
Married at time of birth of second child (1=yes) & 4114 & 0.972 & 0.166 \\
Social class father & 4114 & 3.829 & 1.498 \\
Social class mother & 4114 & 5.128 & 2.457 \\
Smoking behavior mother during pregnancy second child (1=smokes) & 4114 & 0.428 & 0.495 \\
Antenatal care during pregnancy of second child (1=yes) & 4114 & 0.163 & 0.369 \\
Mother's wellbeing at age 5 of second child & 2681 & 0 & 1 \\
Second child lives with same parents since birth (1=yes) & 3017 & 0.889 & 0.314 \\
Mother's attitude to maternal employment & 2913 & 0 & 1 \\
Mother's attitude to sex equality & 2913 & 0 & 1 \\
Mother's attitude to better life for women & 2913 & 0 & 1 \\
Mother's attitude to tv viewing & 2913 & 0 & 1 \\
Mother's attitude to hospital visiting & 2913 & 0 & 1 \\
Mother's authoritarian world view & 2913 & 0 & 1 \\
Mother's authoritarian child rearing & 2913 & 0 & 1 \\
Mother's attitude to child independence & 2913 & 0 & 1 \\
\hline
\end{tabular}

Note: The sample is restricted to two-child families. All personality traits are measured at age 10 of the second (i.e. youngest) child and standardized to mean zero and standard deviation one. Questions related to the Rutter test are answered by the mother. Self-esteem and locus of control questions are answered by the child. Questions related to disorganized, asocial, neurotic and introverted traits are answered by the teacher. A high score on the Rutter test implies more behavioral difficulties. A high score on the locus of control scale implies an internal locus of control. Miscarriages are broadly defined to include the following categories: 'died under 7 days,' 'died 7 days and over,' 'stillbirth,' 'miscarriage,' 'ectopic,' and 'hydatidiform mole.' We define a miscarriage with a narrow definition if the respondents indicated the 'miscarriage' category. In a robustness check we include all other categories (excluding 'alive in April 1970'). Social class mother/father contain 6 categories. See the appendix for more information. Mother's wellbeing at age 5 of the second child is standardized to mean zero and standard deviation one. All variables concerning mother's attitudes are standardized to mean zero and standard deviation one as well. 
Figure 1

Cumulative distribution of the birth gap

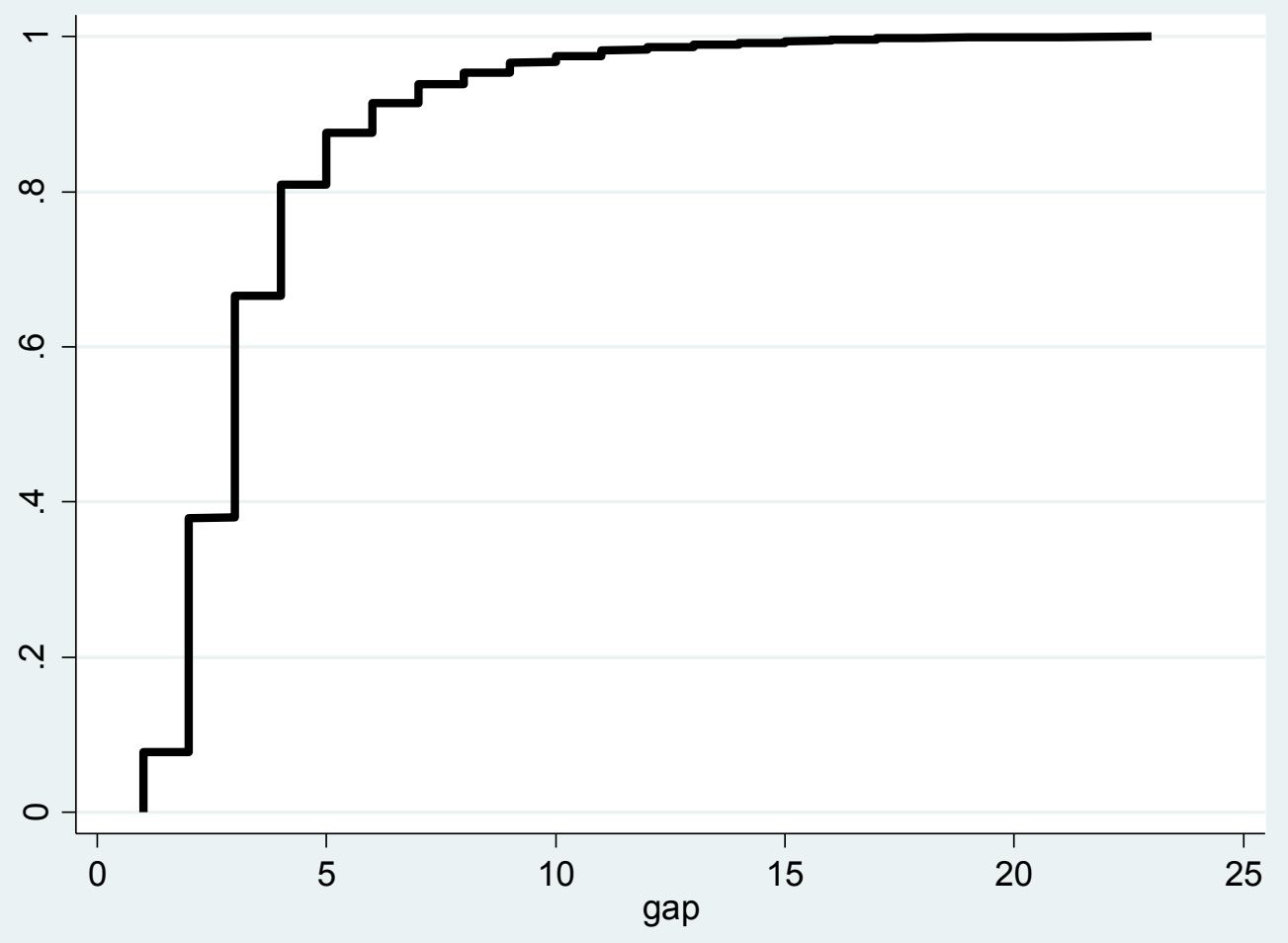

Note: the birth gap is measured in years which explains the stepwise progression. 
Figure 2 Histogram birth gap for miscarriage and no miscarriage

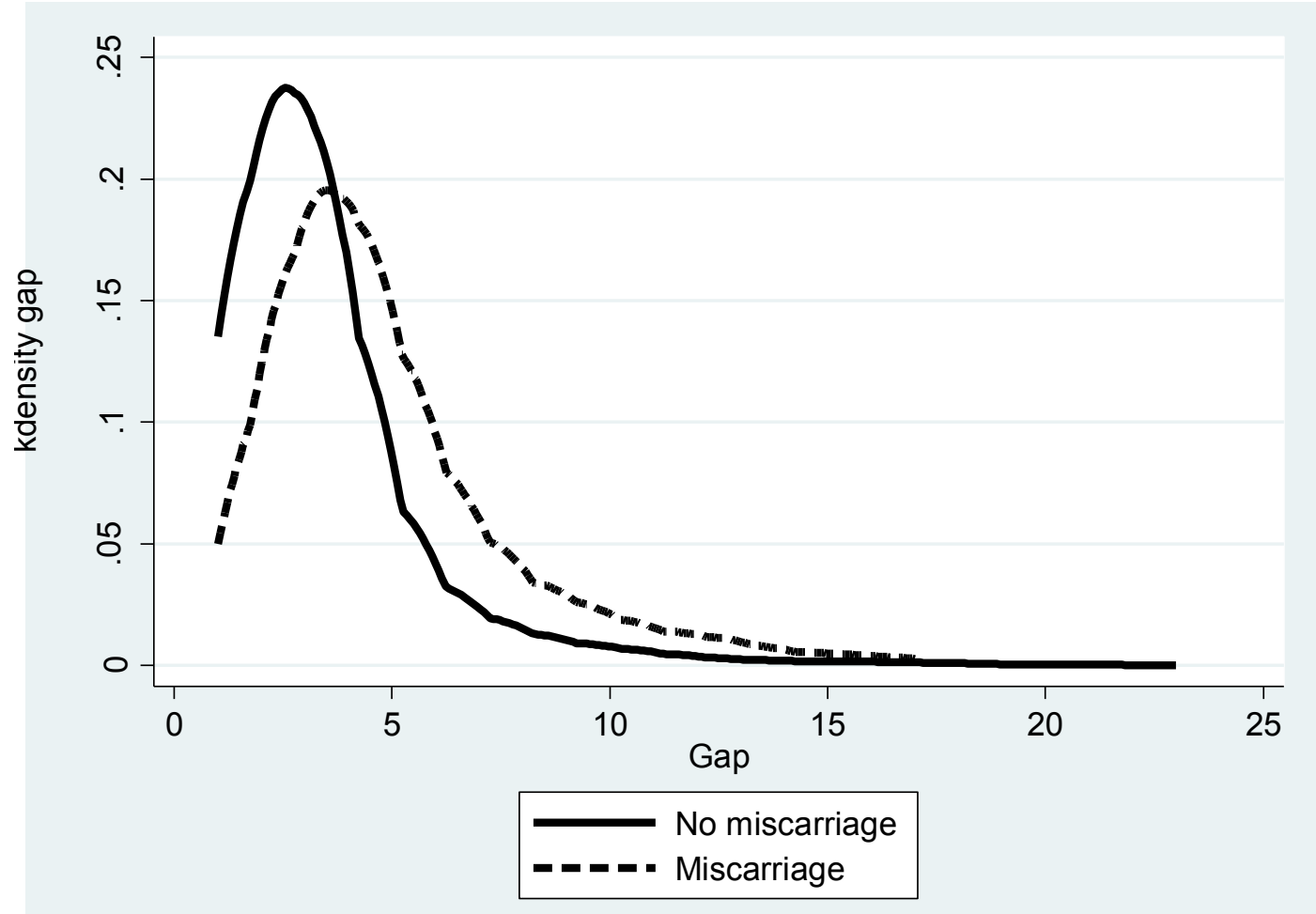

Note: the figure shows two Kernel plots of the birth gap - one for the children for whom the mothers did not have a miscarriage between the siblings, and one for the children for whom the mothers did have a miscarriage in between. 
Table 2 First stage regressions of birth gap on miscarriage

\begin{tabular}{lccc}
\hline & $\begin{array}{c}\text { OLS gap without } \\
\text { controls }\end{array}$ & $\begin{array}{c}\text { OLS gap with a } \\
\text { selection of } \\
\text { controls }\end{array}$ & $\begin{array}{c}\text { OLS gap with all } \\
\text { controls }\end{array}$ \\
\hline $\begin{array}{l}\text { Number of miscarriages between first } \\
\text { and second child (broad) }\end{array}$ & $1.294^{* * *}$ & $1.253^{* * *}$ & $01.294^{* * * *}$ \\
& $(0.075)$ & $(0.075)$ & $(0.109)$ \\
& & & \\
F-statistic (miscarriage) & $296.434^{* * *}$ & $280.341^{* * *}$ & $141.957^{* * *}$ \\
Observations & 4,079 & 4,063 & 2,337 \\
R-squared & 0.068 & 0.097 & 0.105 \\
\hline
\end{tabular}

Note: Each column shows a regression with birth gap as the dependent variable and miscarriage as the independent variable. The first column shows the results when no controls are added to the regressions. The second column adds controls for number of miscarriages between first and second child (broad), gender, mother's age at delivery of first child, married at time of birth of second child, social class father, social class mother, smoking behavior mother during pregnancy second child, antenatal care during pregnancy of second child. The third columns additionally adds controls for mother's wellbeing at age 5 of second child, second child lives with same parents since birth, and mother's attitudes. See table 1 for definitions of these variables and appendix Table A15 for the full regression results including all controls. Standard errors are shown in parentheses. $* * * \mathrm{p}<0.01, * * \mathrm{p}<0.05, * \mathrm{p}<0.1$. 
Table 3 OLS regression of miscarrying on all controls

\begin{tabular}{lc}
\hline & $\begin{array}{c}\text { Miscarriage } \\
\text { between first } \\
\text { and second } \\
\text { child }\end{array}$ \\
\hline Gender (1=male) & -0.010 \\
Mother's age at delivery of first child (in years) & $(0.013)$ \\
Married at time of birth of second child (1=yes) & -0.002 \\
& $(0.002)$ \\
Social class father II & -0.016 \\
Social class father III NM & $(0.044)$ \\
Social class father III M & -0.002 \\
Social class father IV & $(0.032)$ \\
Social class father V & -0.035 \\
Social class father unsupported & $(0.032)$ \\
Social class mother III NM & -0.000 \\
Social class mother III M & $(0.029)$ \\
Social class mother IV & -0.009 \\
Social class mother V & $(0.033)$ \\
Housewives & 0.022 \\
Social class mother unsupported & $(0.041)$ \\
Smoking behavior mother during pregnancy second child (1) smokes) & -0.044 \\
Antenatal care during pregnancy of second child (1=yes) & $(0.043)$ \\
Nr. Miscarriages before the first child (broad) & -0.023 \\
Constant & $(0.029)$ \\
R-squared & -0.024 \\
& $(0.042)$ \\
& 0.004 \\
& $(0.032)$ \\
& -0.112 \\
& $(0.079)$ \\
& -0.019 \\
& $(0.027)$ \\
& -0.005 \\
& $(0.031)$ \\
& 0.012 \\
& $(0.013)$ \\
& $0.085^{* * *}$ \\
& $(0.018)$ \\
& $0.070 * * *$ \\
& $(0.016)$ \\
& $0.181 * *$ \\
& $(0.071)$ \\
& 4,063 \\
& 0.014 \\
\hline
\end{tabular}

Note: Standard errors are shown in parentheses. ${ }^{* * *} \mathrm{p}<0.01,{ }^{* *} \mathrm{p}<0.05,{ }^{*} \mathrm{p}<0.1$ 
Table 4 IV regressions of birth gap on personality

\begin{tabular}{|c|c|c|c|c|c|c|}
\hline & \multicolumn{2}{|c|}{ IV without controls } & \multicolumn{2}{|c|}{$\begin{array}{l}\text { IV with a selection of } \\
\text { controls }\end{array}$} & \multicolumn{2}{|c|}{ IV with all controls } \\
\hline & Coeff. & Obs. & Coeff. & Obs. & Coeff, & Obs. \\
\hline $\begin{array}{l}\text { Rutter behavioral } \\
\text { difficulties }\end{array}$ & $\begin{array}{c}0.044 \\
(0.037)\end{array}$ & 2841 & $\begin{array}{c}0.022 \\
(0.037)\end{array}$ & 2829 & $\begin{array}{c}0.023 \\
(0.044)\end{array}$ & 2220 \\
\hline Self-esteem & $\begin{array}{l}-0.036 \\
(0.038)\end{array}$ & 2631 & $\begin{array}{l}-0.031 \\
(0.039)\end{array}$ & 2605 & $\begin{array}{l}-0.059 \\
(0.054)\end{array}$ & 1889 \\
\hline Locus of control & $\begin{array}{l}-0.025 \\
(0.038)\end{array}$ & 2547 & $\begin{array}{l}-0.017 \\
(0.039)\end{array}$ & 2566 & $\begin{array}{c}0.006 \\
(0.050)\end{array}$ & 1860 \\
\hline Disorganized & $\begin{array}{l}0.109^{* *} \\
(0.044)\end{array}$ & 2537 & $\begin{array}{l}0.101^{* *} \\
(0.045)\end{array}$ & 2528 & $\begin{array}{l}0.107^{*} \\
(0.059)\end{array}$ & 1827 \\
\hline Asocial & $\begin{array}{c}0.033 \\
(0.037)\end{array}$ & 2704 & $\begin{array}{c}0.023 \\
(0.038)\end{array}$ & 2694 & $\begin{array}{c}0.014 \\
(0.050)\end{array}$ & 1948 \\
\hline Neuroticism & $\begin{array}{c}0.089 * * \\
(0.037)\end{array}$ & 2723 & $\begin{array}{r}0.082 * * \\
(0.038)\end{array}$ & 2714 & $\begin{array}{c}0.145^{* * *} \\
(0.053)\end{array}$ & 1955 \\
\hline Introversion & $\begin{array}{c}0.043 \\
(0.038)\end{array}$ & 2721 & $\begin{array}{c}0.039 \\
(0.039)\end{array}$ & 2711 & $\begin{array}{c}0.068 \\
(0.053) \\
\end{array}$ & 1960 \\
\hline
\end{tabular}

Note: Each cell shows the coefficient of a separate IV regression with the variable indicated in the row as the dependent variable and birth gap as the independent variable. The instrument is the number of miscarriages between the siblings. This baseline estimation shows results when the gap range is restricted to 15 years. The first column shows the results when no controls are added to the regressions. The second column adds controls for number of miscarriages between first and second child (broad), gender, mother's age at delivery of first child, married at time of birth of second child, social class father, social class mother, smoking behavior mother during pregnancy second child, antenatal care during pregnancy of second child. The third columns additionally adds controls for mother's wellbeing at age 5 of second child, second child lives with same parents since birth, and mother's attitudes. See table 1 for definitions of these variables. Standard errors are shown in parentheses. ${ }^{* * *} \mathrm{p}<0.01,{ }^{* *} \mathrm{p}<0.05,{ }^{*} \mathrm{p}<0.1$ 
Table 5 IV regressions of birth gap on personality, varying gaps

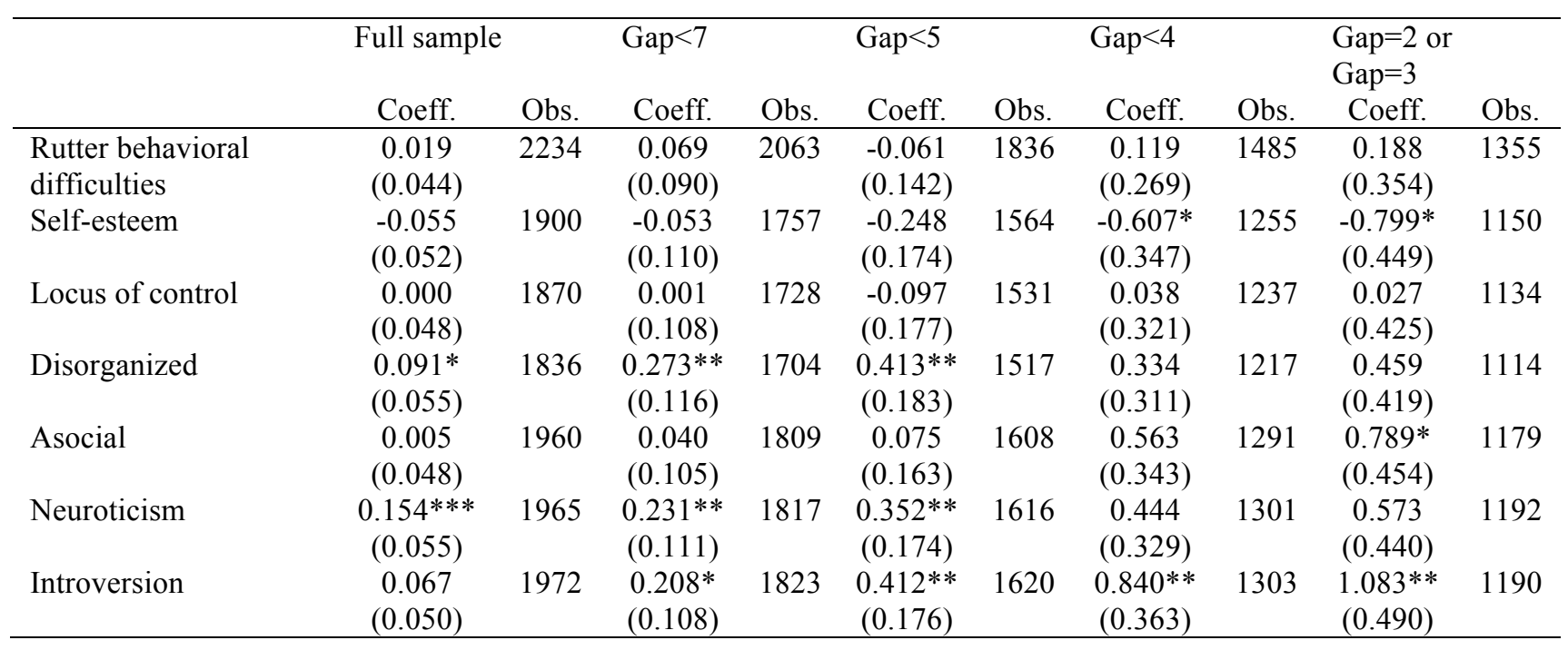

Note: Each cell shows the coefficient of a separate IV regression with the variable indicated in the row as the dependent variable and birth gap as the independent variable. The instrument is the number of miscarriages between the siblings with the broad definition. All columns add controls for number of miscarriages between first and second child (broad), gender, mother's age at delivery of first child, married at time of birth of second child, social class father, social class mother, smoking behavior mother during pregnancy second child, antenatal care during pregnancy of second child, mother's wellbeing at age 5 of second child, second child lives with same parents since birth, and mother's attitudes. See table 1 for definitions of these variables. Standard errors are shown in parentheses. $* * * \mathrm{p}<0.01, * * \mathrm{p}<0.05, * \mathrm{p}<0.1$ 
Table 6 IV regressions of birth gap on personality, narrow definition

\begin{tabular}{|c|c|c|c|c|c|c|c|c|c|c|c|c|}
\hline & \multirow{2}{*}{$\begin{array}{c}\text { Gap }<15 \\
\text { (Baseline) } \\
\text { Coeff. } \\
\end{array}$} & \multirow[b]{2}{*}{ Obs. } & \multirow{2}{*}{$\begin{array}{c}\text { Full sample } \\
\text { Coeff. }\end{array}$} & \multirow[b]{2}{*}{ Obs. } & \multirow{2}{*}{$\begin{array}{c}\text { Gap }<7 \\
\text { Coeff. } \\
\end{array}$} & \multirow[b]{2}{*}{ Obs. } & \multirow{2}{*}{$\begin{array}{c}\text { Gap }<5 \\
\text { Coeff. }\end{array}$} & \multirow[b]{2}{*}{ Obs. } & \multirow{2}{*}{$\begin{array}{c}\text { Gap }<4 \\
\text { Coeff. }\end{array}$} & \multirow[b]{2}{*}{ Obs. } & \multicolumn{2}{|c|}{ Gap $=2$ or Gap $=3$} \\
\hline & & & & & & & & & & & Coeff. & Obs. \\
\hline Rutter behavioral difficulties & $\begin{array}{c}0.033 \\
(0.057)\end{array}$ & 2220 & $\begin{array}{c}0.030 \\
(0.057)\end{array}$ & 2234 & $\begin{array}{c}0.089 \\
(0.105)\end{array}$ & 2063 & $\begin{array}{c}-0.053 \\
(0.158)\end{array}$ & 1836 & $\begin{array}{c}0.131 \\
(0.303)\end{array}$ & 1485 & $\begin{array}{c}0.208 \\
(0.392)\end{array}$ & 1355 \\
\hline Self-esteem & $\begin{array}{l}-0.094 \\
(0.071)\end{array}$ & 1889 & $\begin{array}{l}-0.092 \\
(0.068)\end{array}$ & 1900 & $\begin{array}{l}-0.106 \\
(0.137)\end{array}$ & 1757 & $\begin{array}{l}-0.254 \\
(0.197)\end{array}$ & 1564 & $\begin{array}{c}-0.548 \\
(0.379)\end{array}$ & 1255 & $\begin{array}{l}-0.710 \\
(0.480)\end{array}$ & 1150 \\
\hline Locus of control & $\begin{array}{l}-0.055 \\
(0.070)\end{array}$ & 1860 & $\begin{array}{c}-0.056 \\
(0.066)\end{array}$ & 1870 & $\begin{array}{l}-0.074 \\
(0.141\end{array}$ & 1728 & $\begin{array}{l}-0.071 \\
(0.201)\end{array}$ & 1531 & $\begin{array}{l}-0.049 \\
(0.352)\end{array}$ & 1237 & $\begin{array}{l}-0.081 \\
(0.459)\end{array}$ & 1134 \\
\hline Disorganized & $\begin{array}{c}0.175 * * \\
(0.079)\end{array}$ & 1827 & $\begin{array}{c}0.157 * * \\
(0.074)\end{array}$ & 1836 & $\begin{array}{c}0.384 * * \\
(0.153)\end{array}$ & 1704 & $\begin{array}{c}0.430 * * \\
(0.203)\end{array}$ & 1517 & $\begin{array}{c}0.459 \\
(0.360)\end{array}$ & 1217 & $\begin{array}{c}0.592 \\
(0.473)\end{array}$ & 1114 \\
\hline Asocial & $\begin{array}{c}0.029 \\
(0.066)\end{array}$ & 1948 & $\begin{array}{c}0.021 \\
(0.064)\end{array}$ & 1960 & $\begin{array}{c}0.068 \\
(0.133)\end{array}$ & 1809 & $\begin{array}{c}0.035 \\
(0.183)\end{array}$ & 1608 & $\begin{array}{c}0.467 \\
(0.376)\end{array}$ & 1291 & $\begin{array}{c}0.614 \\
(0.485)\end{array}$ & 1179 \\
\hline Neuroticism & $\begin{array}{c}0.192 * * * \\
(0.070)\end{array}$ & 1955 & $\begin{array}{c}0.202 * * * \\
(0.072)\end{array}$ & 1965 & $\begin{array}{l}0.260^{*} \\
(0.140)\end{array}$ & 1817 & $\begin{array}{l}0.326^{*} \\
(0.192)\end{array}$ & 1616 & $\begin{array}{c}0.363 \\
(0.363)\end{array}$ & 1301 & $\begin{array}{c}0.444 \\
(0.473)\end{array}$ & 1192 \\
\hline Introversion & $\begin{array}{c}0.107 \\
(0.071)\end{array}$ & 1960 & $\begin{array}{c}0.104 \\
(0.069)\end{array}$ & 1972 & $\begin{array}{l}0.251^{*} \\
(0.139)\end{array}$ & 1823 & $\begin{array}{l}0.355^{*} \\
(0.198)\end{array}$ & 1620 & $\begin{array}{c}0.864 * * \\
(0.410)\end{array}$ & 1303 & $\begin{array}{l}1.087 * * \\
(0.541)\end{array}$ & 1190 \\
\hline
\end{tabular}

Note: Each cell shows the coefficient of a separate IV regression with the variable indicated in the row as the dependent variable and birth gap as the independent variable. The instrument is the number of miscarriages between the siblings with the narrow definition. All columns add controls for number of miscarriages between first and second child (broad), gender, mother's age at delivery of first child, married at time of birth of second child, social class father, social class mother, smoking behavior mother during pregnancy second child, antenatal care during pregnancy of second child, mother's wellbeing at age 5 of second child, second child lives with same parents since birth, and mother's attitudes. See table 1 for definitions of these variables. Standard errors are shown in parentheses. $* * * \mathrm{p}<0.01, * * \mathrm{p}<0.05, * \mathrm{p}<0.1$ 
Table 7 IV regressions of birth gap on personality, boys

\begin{tabular}{|c|c|c|c|c|c|c|c|c|c|c|c|c|}
\hline & \multirow{2}{*}{$\begin{array}{c}\text { Gap }<15 \\
\text { (Baseline) } \\
\text { Coeff. } \\
\end{array}$} & \multirow[b]{2}{*}{ Obs. } & \multirow{2}{*}{$\begin{array}{c}\text { Full sample } \\
\text { Coeff. }\end{array}$} & \multirow[b]{2}{*}{ Obs. } & \multirow{2}{*}{$\begin{array}{c}\text { Gap }<7 \\
\text { Coeff. } \\
\end{array}$} & \multirow[b]{2}{*}{ Obs. } & \multirow{2}{*}{$\begin{array}{c}\text { Gap }<5 \\
\text { Coeff. }\end{array}$} & \multirow[b]{2}{*}{ Obs. } & \multirow{2}{*}{$\begin{array}{c}\text { Gap }<4 \\
\text { Coeff. }\end{array}$} & \multirow[b]{2}{*}{ Obs. } & \multicolumn{2}{|c|}{ Gap $=2$ or Gap $=3$} \\
\hline & & & & & & & & & & & Coeff. & Obs. \\
\hline Rutter behavioral difficulties & $\begin{array}{c}-0.012 \\
(0.049)\end{array}$ & 1164 & $\begin{array}{c}-0.016 \\
(0.047)\end{array}$ & 1173 & $\begin{array}{c}0.005 \\
(0.105)\end{array}$ & 1087 & $\begin{array}{c}-0.159 \\
(0.174)\end{array}$ & 968 & $\begin{array}{c}0.185 \\
(0.465)\end{array}$ & 766 & $\begin{array}{c}0.243 \\
(0.595)\end{array}$ & 689 \\
\hline Self-esteem & $\begin{array}{l}-0.011 \\
(0.055)\end{array}$ & 989 & $\begin{array}{l}-0.009 \\
(0.049)\end{array}$ & 995 & $\begin{array}{c}0.060 \\
(0.124)\end{array}$ & 924 & $\begin{array}{l}-0.083 \\
(0.185)\end{array}$ & 831 & $\begin{array}{l}-0.597 \\
(0.466)\end{array}$ & 655 & $\begin{array}{c}-0.756 \\
(0.654)\end{array}$ & 589 \\
\hline Locus of control & $\begin{array}{c}0.020 \\
(0.053)\end{array}$ & 957 & $\begin{array}{c}0.011 \\
(0.048)\end{array}$ & 963 & $\begin{array}{c}0.044 \\
(0.136)\end{array}$ & 892 & $\begin{array}{c}-0.054 \\
(0.204)\end{array}$ & 801 & $\begin{array}{c}0.288 \\
(0.461)\end{array}$ & 634 & $\begin{array}{c}0.411 \\
(0.624)\end{array}$ & 572 \\
\hline Disorganized & $\begin{array}{c}0.073 \\
(0.066)\end{array}$ & 951 & $\begin{array}{c}0.053 \\
(0.058)\end{array}$ & 956 & $\begin{array}{l}0.263 * \\
(0.153)\end{array}$ & 889 & $\begin{array}{l}0.411 * \\
(0.222)\end{array}$ & 799 & $\begin{array}{c}0.380 \\
(0.453)\end{array}$ & 626 & $\begin{array}{c}0.487 \\
(0.605)\end{array}$ & 562 \\
\hline Asocial & $\begin{array}{c}-0.034 \\
(0.060)\end{array}$ & 1017 & $\begin{array}{l}-0.042 \\
(0.055)\end{array}$ & 1024 & $\begin{array}{l}-0.074 \\
(0.144)\end{array}$ & 948 & $\begin{array}{l}-0.163 \\
(0.207)\end{array}$ & 852 & $\begin{array}{c}0.350 \\
(0.533)\end{array}$ & 667 & $\begin{array}{c}0.452 \\
(0.698)\end{array}$ & 600 \\
\hline Neuroticism & $\begin{array}{c}0.116 * * \\
(0.056)\end{array}$ & 1018 & $\begin{array}{c}0.121^{* *} \\
(0.055)\end{array}$ & 1024 & $\begin{array}{c}0.118 \\
(0.135)\end{array}$ & 951 & $\begin{array}{c}0.232 \\
(0.200)\end{array}$ & 857 & $\begin{array}{c}0.106 \\
(0.456)\end{array}$ & 675 & $\begin{array}{c}0.131 \\
(0.590)\end{array}$ & 610 \\
\hline Introversion & $\begin{array}{c}0.035 \\
(0.059)\end{array}$ & 1019 & $\begin{array}{c}0.035 \\
(0.054)\end{array}$ & 1026 & $\begin{array}{c}0.124 \\
(0.135)\end{array}$ & 952 & $\begin{array}{c}0.280 \\
(0.201)\end{array}$ & 857 & $\begin{array}{c}0.594 \\
(0.496)\end{array}$ & 674 & $\begin{array}{c}0.709 \\
(0.652)\end{array}$ & 606 \\
\hline
\end{tabular}

Note: Each cell shows the coefficient of a separate IV regression with the variable indicated in the row as the dependent variable and birth gap as the independent variable. The instrument is the number of miscarriages between the siblings with the broad definition. All columns add controls for number of miscarriages between first and second child (broad), gender, mother's age at delivery of first child, married at time of birth of second child, social class father, social class mother, smoking behavior mother during pregnancy second child, antenatal care during pregnancy of second child, mother's wellbeing at age 5 of second child, second child lives with same parents since birth, and mother's attitudes. See table 1 for definitions of these variables. Standard errors are shown in parentheses. $* * * \mathrm{p}<0.01, * * \mathrm{p}<0.05, * \mathrm{p}<0.1$ 
Table 8 IV regressions of birth gap on personality, girls

\begin{tabular}{|c|c|c|c|c|c|c|c|c|c|c|c|c|}
\hline & \multirow{2}{*}{$\begin{array}{c}\text { Gap }<15 \\
\text { (Baseline) } \\
\text { Coeff. } \\
\end{array}$} & \multirow[b]{2}{*}{ Obs. } & \multirow{2}{*}{$\begin{array}{c}\text { Full sample } \\
\text { Coeff. }\end{array}$} & \multirow[b]{2}{*}{ Obs. } & \multirow{2}{*}{$\begin{array}{c}\text { Gap }<7 \\
\text { Coeff. } \\
\end{array}$} & \multirow[b]{2}{*}{ Obs. } & \multirow{2}{*}{$\begin{array}{c}\text { Gap }<5 \\
\text { Coeff. }\end{array}$} & \multirow[b]{2}{*}{ Obs. } & \multirow{2}{*}{$\begin{array}{c}\text { Gap }<4 \\
\text { Coeff. }\end{array}$} & \multirow[b]{2}{*}{ Obs. } & \multicolumn{2}{|c|}{ Gap $=2$ or Gap $=3$} \\
\hline & & & & & & & & & & & Coeff. & Obs. \\
\hline Rutter behavioral difficulties & $\begin{array}{c}0.099 \\
(0.101)\end{array}$ & 1056 & $\begin{array}{c}0.108 \\
(0.113)\end{array}$ & 1061 & $\begin{array}{c}0.147 \\
(0.166)\end{array}$ & 976 & $\begin{array}{c}0.021 \\
(0.246)\end{array}$ & 868 & $\begin{array}{c}0.078 \\
(0.325)\end{array}$ & 719 & $\begin{array}{c}0.092 \\
(0.438)\end{array}$ & 666 \\
\hline Self-esteem & $\begin{array}{l}-0.175 \\
(0.131)\end{array}$ & 900 & $\begin{array}{l}-0.200 \\
(0.155)\end{array}$ & 905 & $\begin{array}{l}-0.190 \\
(0.193)\end{array}$ & 833 & $\begin{array}{l}-0.507 \\
(0.342)\end{array}$ & 733 & $\begin{array}{c}-0.689 \\
(0.508)\end{array}$ & 600 & $\begin{array}{l}-0.892 \\
(0.640)\end{array}$ & 561 \\
\hline Locus of control & $\begin{array}{l}-0.022 \\
(0.124)\end{array}$ & 903 & $\begin{array}{l}-0.024 \\
(0.140)\end{array}$ & 907 & $\begin{array}{l}-0.032 \\
(0.171)\end{array}$ & 836 & $\begin{array}{l}-0.162 \\
(0.330)\end{array}$ & 730 & $\begin{array}{c}-0.134 \\
(0.451)\end{array}$ & 603 & $\begin{array}{c}-0.247 \\
(0.607)\end{array}$ & 562 \\
\hline Disorganized & $\begin{array}{c}0.199 \\
(0.138)\end{array}$ & 876 & $\begin{array}{c}0.224 \\
(0.159)\end{array}$ & 880 & $\begin{array}{c}0.267 \\
(0.167)\end{array}$ & 815 & $\begin{array}{c}0.441 \\
(0.310)\end{array}$ & 718 & $\begin{array}{c}0.317 \\
(0.404)\end{array}$ & 591 & $\begin{array}{c}0.418 \\
(0.544)\end{array}$ & 552 \\
\hline Asocial & $\begin{array}{c}0.125 \\
(0.100)\end{array}$ & 931 & $\begin{array}{c}0.144 \\
(0.116)\end{array}$ & 936 & $\begin{array}{c}0.168 \\
(0.147)\end{array}$ & 861 & $\begin{array}{l}0.455^{*} \\
(0.272)\end{array}$ & 756 & $\begin{array}{c}0.794 \\
(0.430)\end{array}$ & 624 & $\begin{array}{l}1.098^{*} \\
(0.589)\end{array}$ & 579 \\
\hline Neuroticism & $\begin{array}{l}0.219^{*} \\
(0.132)\end{array}$ & 937 & $\begin{array}{c}0.252 \\
(0.154)\end{array}$ & 941 & $\begin{array}{l}0.360^{*} \\
(0.185)\end{array}$ & 866 & $\begin{array}{c}0.526 \\
(0.324)\end{array}$ & 759 & $\begin{array}{c}0.604^{*} \\
(0.480)\end{array}$ & 626 & $\begin{array}{c}0.792 \\
(0.653)\end{array}$ & 582 \\
\hline Introversion & $\begin{array}{c}0.149 \\
(0.109)\end{array}$ & 941 & $\begin{array}{c}0.162 \\
(0.124)\end{array}$ & 946 & $\begin{array}{l}0.317^{*} \\
(0.173)\end{array}$ & 871 & $\begin{array}{l}0.653^{*} \\
(0.334)\end{array}$ & 763 & $\begin{array}{c}1.014^{*} \\
(0.518)\end{array}$ & 629 & $\begin{array}{l}1.361^{*} \\
(0.725)\end{array}$ & 584 \\
\hline
\end{tabular}

Note: Each cell shows the coefficient of a separate IV regression with the variable indicated in the row as the dependent variable and birth gap as the independent variable. The instrument is the number of miscarriages between the siblings with the broad definition. All columns add controls for number of miscarriages between first and second child (broad), gender, mother's age at delivery of first child, married at time of birth of second child, social class father, social class mother, smoking behavior mother during pregnancy second child, antenatal care during pregnancy of second child, mother's wellbeing at age 5 of second child, second child lives with same parents since birth, and mother's attitudes. See table 1 for definitions of these variables. Standard errors are shown in parentheses. $* * * \mathrm{p}<0.01, * * \mathrm{p}<0.05, * \mathrm{p}<0.1$ 
Table 9 IV regressions of birth gap on achievement tests, education and other life outcomes

\begin{tabular}{|c|c|c|c|c|c|c|c|}
\hline & & \multicolumn{2}{|c|}{$\begin{array}{l}\text { IV regression of birth gap without } \\
\text { controls }\end{array}$} & \multicolumn{2}{|c|}{$\begin{array}{l}\text { IV regression of birth gap with a } \\
\text { selection of controls }\end{array}$} & \multicolumn{2}{|c|}{$\begin{array}{l}\text { IV regression of birth gap with all } \\
\text { controls }\end{array}$} \\
\hline & & Coeff. & Obs. & Coeff. & Obs. & Coeff. & Obs. \\
\hline \multirow{13}{*}{ 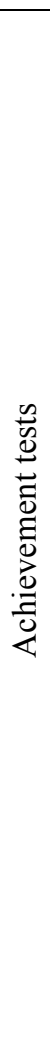 } & EPVT cognitive test (age 5) & $\begin{array}{c}0.004 \\
(0.035)\end{array}$ & 2713 & $\begin{array}{c}0.012 \\
(0.035)\end{array}$ & 2704 & $\begin{array}{l}-0.013 \\
(0.041)\end{array}$ & 2199 \\
\hline & $\begin{array}{l}\text { Human figure drawing } \\
\text { cognitive test (age 5) }\end{array}$ & $\begin{array}{l}-0.006 \\
(0.036)\end{array}$ & 2838 & $\begin{array}{l}-0.007 \\
(0.037)\end{array}$ & 2829 & $\begin{array}{l}-0.035 \\
(0.046)\end{array}$ & 2299 \\
\hline & $\begin{array}{l}\text { Copy designs cognitive test } \\
\text { (age 5) }\end{array}$ & $\begin{array}{l}-0.009 \\
(0.035)\end{array}$ & 2874 & $\begin{array}{c}0.004 \\
(0.035)\end{array}$ & 2865 & $\begin{array}{l}-0.036 \\
(0.044)\end{array}$ & 2327 \\
\hline & $\begin{array}{l}\text { Edinburgh Reading Test (age } \\
\text { 10) }\end{array}$ & $\begin{array}{l}-0.016 \\
(0.064)\end{array}$ & 955 & $\begin{array}{l}-0.009 \\
(0.062)\end{array}$ & 952 & $\begin{array}{c}0.096 \\
(0.082)\end{array}$ & 710 \\
\hline & Friendly Math Test (age 10) & $\begin{array}{c}-0.130 * * \\
(0.057)\end{array}$ & 891 & $\begin{array}{r}-0.106^{*} \\
(0.055)\end{array}$ & 887 & $\begin{array}{l}-0.052 \\
(0.072)\end{array}$ & 653 \\
\hline & Vocabulary Test (age 10) & $\begin{array}{l}-0.009 \\
(0.036)\end{array}$ & 2807 & $\begin{array}{l}-0.007 \\
(0.037)\end{array}$ & 2797 & $\begin{array}{c}0.004 \\
(0.048)\end{array}$ & 2022 \\
\hline & Reading Test (age 10) & $\begin{array}{l}0.064 * \\
(0.036)\end{array}$ & 2807 & $\begin{array}{l}0.062 * \\
(0.037)\end{array}$ & 2797 & $\begin{array}{c}0.057 \\
(0.050)\end{array}$ & 2021 \\
\hline & Spelling Test (age 10) & $\begin{array}{l}-0.039 \\
(0.048)\end{array}$ & 2125 & $\begin{array}{l}-0.027 \\
(0.049)\end{array}$ & 2118 & $\begin{array}{c}0.001 \\
(0.069)\end{array}$ & 1525 \\
\hline & Sequence Test (age 10) & $\begin{array}{c}0.007 \\
(0.038)\end{array}$ & 2521 & $\begin{array}{c}0.015 \\
(0.037)\end{array}$ & 2514 & $\begin{array}{c}0.040 \\
(0.050)\end{array}$ & 1824 \\
\hline & Sentence Test (age 10) & $\begin{array}{c}0.032 \\
(0.036)\end{array}$ & 2641 & $\begin{array}{c}0.019 \\
(0.037)\end{array}$ & 2634 & $\begin{array}{c}0.015 \\
(0.050)\end{array}$ & 1900 \\
\hline & Math Score (age 16) & $\begin{array}{c}0.055 \\
(0.078)\end{array}$ & 849 & $\begin{array}{c}0.016 \\
(0.073)\end{array}$ & 846 & $\begin{array}{c}0.115 \\
(0.093)\end{array}$ & 614 \\
\hline & Spelling Test (age 16) & $\begin{array}{c}0.096 \\
(0.065)\end{array}$ & 1376 & $\begin{array}{l}0.116^{*} \\
(0.062)\end{array}$ & 1373 & $\begin{array}{c}0.126 \\
(0.079)\end{array}$ & 1004 \\
\hline & Vocabulary Test (age 16) & $\begin{array}{c}0.004 \\
(0.064)\end{array}$ & 1376 & $\begin{array}{c}0.022 \\
(0.063)\end{array}$ & 1373 & $\begin{array}{c}0.002 \\
(0.081)\end{array}$ & 1004 \\
\hline
\end{tabular}




\begin{tabular}{|c|c|c|c|c|c|c|}
\hline Grade Point Average age 16 & $\begin{array}{c}0.010 \\
(0.054)\end{array}$ & 1463 & $\begin{array}{c}0.001 \\
(0.054)\end{array}$ & 1459 & $\begin{array}{c}0.026 \\
(0.063)\end{array}$ & 1094 \\
\hline $\begin{array}{l}\text { Age left school (measured at } \\
\text { age 26) }\end{array}$ & $\begin{array}{l}-0.069 \\
(0.046)\end{array}$ & 2071 & $\begin{array}{l}-0.066 \\
(0.045)\end{array}$ & 2066 & $\begin{array}{c}0.001 \\
(0.060)\end{array}$ & 1452 \\
\hline Highest qualification at age 26 & $\begin{array}{l}-0.047 \\
(0.047)\end{array}$ & 1995 & $\begin{array}{l}-0.031 \\
(0.044)\end{array}$ & 1990 & $\begin{array}{l}-0.006 \\
(0.060)\end{array}$ & 1401 \\
\hline $\begin{array}{l}\text { Age left education (graduation } \\
\text { age corrected for highest } \\
\text { qualification) }\end{array}$ & $\begin{array}{l}-0.078^{*} \\
(0.041)\end{array}$ & 2204 & $\begin{array}{l}-0.067^{*} \\
(0.040)\end{array}$ & 2193 & $\begin{array}{l}-0.020 \\
(0.051)\end{array}$ & 1568 \\
\hline Body Mass Index & $\begin{array}{c}0.062 \\
(0.044)\end{array}$ & 2142 & $\begin{array}{l}0.060 \\
(0.045)\end{array}$ & 2131 & $\begin{array}{l}0.101 * \\
(0.061)\end{array}$ & 1523 \\
\hline $\begin{array}{l}\overline{0} \\
\stackrel{0}{0}\end{array}$ & $\begin{array}{c}0.032 \\
(0.041)\end{array}$ & 2195 & $\begin{array}{c}0.021 \\
(0.042)\end{array}$ & 2184 & $\begin{array}{l}-0.038 \\
(0.055)\end{array}$ & 1562 \\
\hline Life Satisfaction & $\begin{array}{l}-0.052 \\
(0.041)\end{array}$ & 2195 & $\begin{array}{l}-0.040 \\
(0.042)\end{array}$ & 2184 & $\begin{array}{c}0.034 \\
(0.054)\end{array}$ & 1562 \\
\hline$\stackrel{\bar{E}}{\tilde{0}}$ & $\begin{array}{l}-0.043 \\
(0.059)\end{array}$ & 1159 & $\begin{array}{l}-0.045 \\
(0.063)\end{array}$ & 1156 & $\begin{array}{l}-0.063 \\
(0.079)\end{array}$ & 834 \\
\hline
\end{tabular}

Note: Each cell shows the coefficient of a separate IV regression with the variable indicated in the row as the dependent variable and birth gap as the independent variable. The instrument is the number of miscarriages between the siblings with the broad definition. All columns add controls for number of miscarriages between first and second child (broad), gender, mother's age at delivery of first child, married at time of birth of second child, social class father, social class mother, smoking behavior mother during pregnancy second child, antenatal care during pregnancy of second child, mother's wellbeing at age 5 of second child, second child lives with same parents since birth, and mother's attitudes. See table 1 for definitions of these variables. For definitions of the dependent variables, see e.g. Borghans et al. 2016. Standard errors are shown in parentheses. ${ }^{* * *} \mathrm{p}<0.01,{ }^{* *} \mathrm{p}<0.05,{ }^{*} \mathrm{p}<0.1$ 


\section{APPENDIX}

Table A1 Panel attrition

\begin{tabular}{|l|l|l|l|l|l|l|l|l|l|}
\hline Year of Sample & 1970 & 1975 & 1980 & 1986 & 1996 & 2000 & 2004 & 2008 & 2012 \\
\hline $\begin{array}{l}\text { Age of } \\
\text { respondents }\end{array}$ & 0 & 5 & 10 & 16 & 26 & 30 & 34 & 38 & 42 \\
\hline Obs. & 17,196 & 13,135 & 14,875 & 11,615 & 9,003 & 11,261 & 9,665 & 8,874 & 9,841 \\
\hline
\end{tabular}

Source: Feinstein (2000)

Table A2 Miscarriages between first and second child (broad definition)

\begin{tabular}{ll}
\hline Nr. miscarriages & Frequencies \\
\hline 0 & 3,712 \\
1 & 337 \\
2 & 46 \\
3 & 15 \\
4 & 3 \\
9 & 1 \\
\hline
\end{tabular}

Table A3 Miscarriages between first and second child (narrow definition)

\begin{tabular}{ll}
\hline Nr. miscarriages & Frequencies \\
\hline 0 & 3,794 \\
1 & 275 \\
2 & 30 \\
3 & 11 \\
4 & 3 \\
9 & 1 \\
\hline
\end{tabular}


Table A4 Questions about Rutter score answered by the mother when the youngest child was 10 years old

- Very restless. Often running about or jumping up and down. Hardly ever still.

- Squirmy or fidgety

- Often destroys own or others' belongings

- Frequently fights with other children

- Not much liked by other children

- Often worried, worries about many things

- Tends to do things on his own - rather solitary

- Irritable. Is quick to "fly off the handle"

- Often appears miserable, unhappy, tearful or distressed

- Sometimes takes things belonging to others

- Has twitches, mannerisms or tics of the face or body

- Frequently sucks thumb or finger

- Frequently bites nails or fingers

- Is often disobedient

- Cannot settle to anything for more than a few moments

- Tends to be fearful or afraid of new things or new situations

- Is fussy or over particular

- Often tells lies

- Bullies other children

Table A5 Questions about self-esteem answered by youngest child at age 10

- Do you think that your parents usually like to hear about your ideas?

- Do you often feel lonely at school?

- Do other children often break friendships or fall out with you?

- Do you think that other children often say nasty things about you?

- When you have to say things in front of the teacher, do you usually feel shy?

- Do you often feel sad because you have nobody to play with at school?

- Are there lots of things about yourself you would like to change?

- When you have to say things in front of other children, do you usually feel foolish?

- When you want to tell a teacher something, do you usually feel foolish?

- Do you often have to find new friends because your old friends are playing with somebody else?

- Do you usually feel foolish when you talk to your parents?

- Do other people often think that you tell lies? 
Table A6 Questions about locus of control answered by youngest child at age 10

- Do you feel that most of the time It's not worth trying hard because things never turn out right anyway?

- Do you feel that wishing can make good things happen?

- Are people good to you no matter how you act towards them?

- Do you usually feel that it's almost useless to try in school because most children are cleverer than you?

- Is a high mark just a matter of "luck" for you?

- Are tests just a lot of guesswork for you?

- Are you often blamed for things which just aren't your fault?

- Are you the kind of person who believes that planning ahead makes things turn out better?

- Do you find it easy to get up in the morning?

- When bad things happen to you, it's usually someone else's fault?

- When someone is very angry with you, is it impossible to make him your friend again?

- When nice things happen to you is it only good luck?

- Do you feel sad when it's time to leave school each day?

- When you get into an argument it is usually the other person's fault?

- Are you surprised when your teacher says you've done well?

- Do you usually get low marks, even when you study hard?

- Do you think studying for a test is a waste of time?

Table A7 Questions about disorganized, asocial, neurotic and introverted behavior answered by the teacher when the youngest child was 10 years old

\begin{tabular}{|c|c|c|c|}
\hline Disorganized & Asocial & Neurotic & Introverted \\
\hline $\begin{array}{ll}\text { - } & \text { Daydreaming } \\
\text { - } & \text { connot } \\
\text { - } & \text { Bored in class } \\
\text { - } & \text { Perseverance } \\
\text { - } & \text { Confused with } \\
& \text { difficult tasks } \\
\text { - } & \text { Easily } \\
& \text { distracted } \\
\text { - } & \text { Pays attention } \\
\text { - } & \text { Forgetful with } \\
& \text { complex task } \\
\text { - } & \text { Lethargic, } \\
& \text { listless } \\
\text { - Completes } \\
\text { - tasks } \\
\text { Falls to finish } \\
\text { tasks }\end{array}$ & $\begin{array}{ll}\text { - } & \text { Complains } \\
\text { about things } \\
\text { - } & \text { Displays } \\
\text { temper } \\
\text { - } & \text { Teases to } \\
\text { excess } \\
\text { - } & \text { Interferes with } \\
\text { others } \\
\text { - } \quad \text { Changes mood } \\
\text { - } \text { quickly } \\
\text { - } \text { ouarrels with } \\
\text { - } \text { Destroys } \\
\text { - } \text { belongings } \\
\text { - Sullies } \\
\text { - Sullen/Sulky } \\
\text { Easily } \\
\text { frustrated }\end{array}$ & $\begin{array}{ll}\text { - } & \text { Afraid of new } \\
\text { things } \\
\text { - } & \text { Behaves } \\
\text { nervously } \\
\text { - } & \text { Fussy } \\
\text { - } & \text { Worried, } \\
& \text { anxious }\end{array}$ & $\begin{array}{ll}- & \text { Excitable, } \\
& \text { impulsive } \\
\text { - } & \text { Solitary child } \\
\text { - } & \text { Lethargic, } \\
& \text { listless } \\
\text { - } & \text { Sullen/ sulky }\end{array}$ \\
\hline
\end{tabular}


Figure A1 Mother's age at time of delivery of the first child

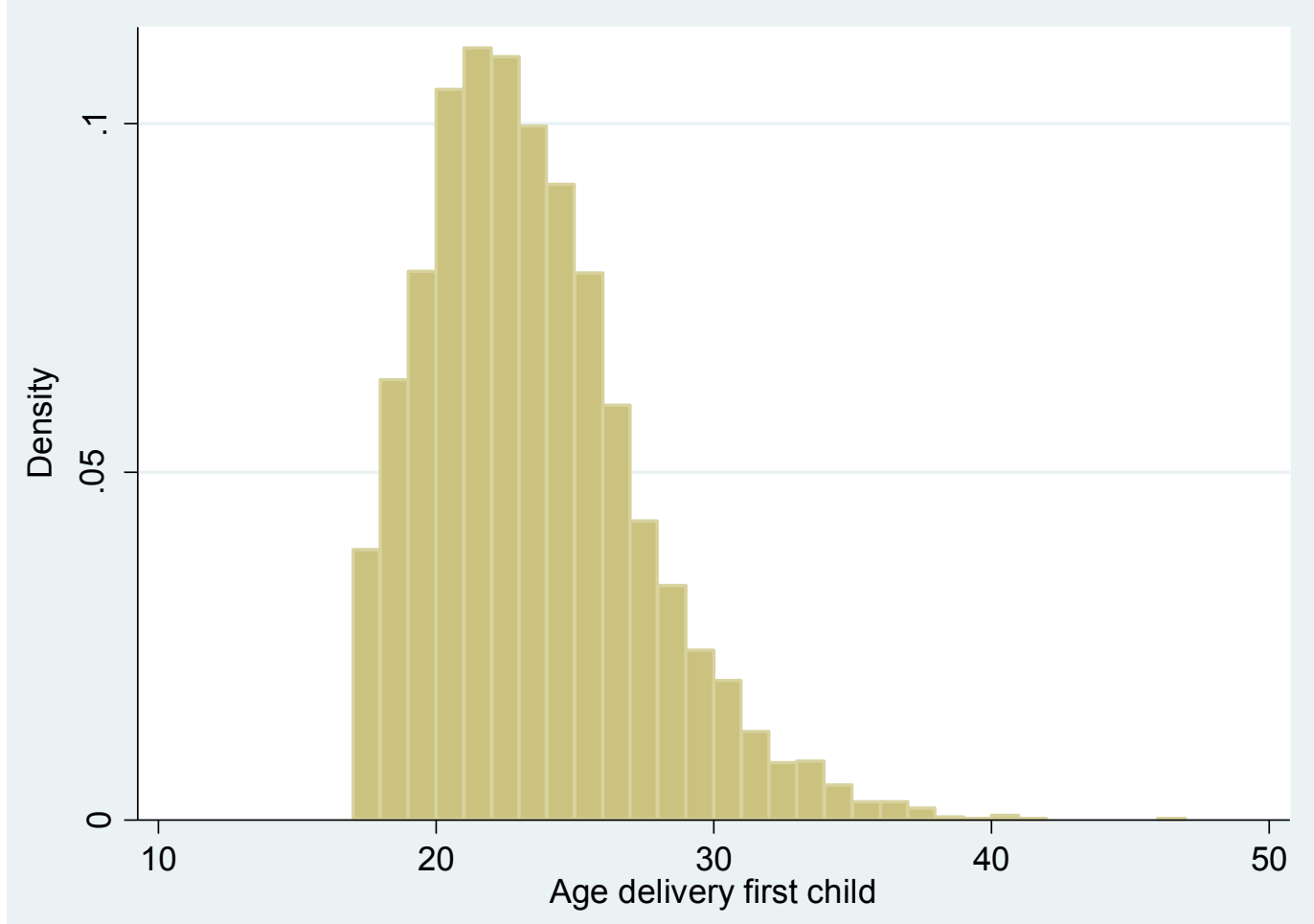

Table A8 Smoking behavior mother during pregnancy of youngest child

\begin{tabular}{lc}
\hline Non-smoker & $44.9 \%$ \\
Stopped pre-pregnancy & $12.2 \%$ \\
Stopped during pregnancy & $3.8 \%$ \\
Smoked 1-4 cigarettes a day during pregnancy & $6.9 \%$ \\
Smoked 5-14 cigarettes a day during pregnancy & $19.5 \%$ \\
Smoked $>15$ cigarettes a day during pregnancy & $12.7 \%$ \\
\hline Total & $100 \%$
\end{tabular}


Table A9 Social class husband at time of birth of youngest child

\begin{tabular}{|c|c|c|}
\hline Social class number & Description of social class & Frequencies \\
\hline Social class I & $\begin{array}{l}\text { Professional occupations, including doctors, lawyers, ministers } \\
\text { of religion, university teachers, professional engineers, etc. }\end{array}$ & 243 \\
\hline Social class II & $\begin{array}{l}\text { Managerial and other processionals, including nurses, school } \\
\text { teachers, company directors, etc. }\end{array}$ & 543 \\
\hline Social class III NM & $\begin{array}{l}\text { Non-manual skilled occupations, including ship assistants, } \\
\text { company representatives, clerical workers, draughtsman, etc. }\end{array}$ & 568 \\
\hline Social class III M & $\begin{array}{l}\text { Skilled manual workers, including mechanics, craftsmen of all } \\
\text { types, skilled engineers, etc. }\end{array}$ & 1,862 \\
\hline Social class IV & $\begin{array}{l}\text { Semi-skilled workers, including machine operators, postmen, } \\
\text { storekeepers, porters, caretakers, etc. }\end{array}$ & 511 \\
\hline Social V & Unskilled workers, including laborers, cleaners, dustmen, etc. & 190 \\
\hline Social class unsupported & Unsupported social class & 197 \\
\hline
\end{tabular}

Table A10 Social class mother at time of birth of youngest child

\begin{tabular}{lll}
\hline Social class number & Description of social class & Frequencies \\
\hline Social class I\&II & $\begin{array}{l}\text { Professional occupations, including doctors, lawyers, ministers of } \\
\text { religion, university teachers, professional engineers, managerial } \\
\text { and other processionals, including nurses, school teachers, } \\
\text { company directors, etc. }\end{array}$ & 297 \\
Social class III NM & $\begin{array}{l}\text { Non-manual skilled occupations, including ship assistants, } \\
\text { company representatives, clerical workers, draughtsman, etc. }\end{array}$ & 820 \\
Social class III M & $\begin{array}{l}\text { Skilled manual workers, including mechanics, craftsmen of all } \\
\text { types, skilled engineers, etc. }\end{array}$ & 158 \\
Social class IV & $\begin{array}{l}\text { Semi-skilled workers, including machine operators, postmen, } \\
\text { storekeepers, porters, caretakers, etc. }\end{array}$ & 543 \\
Social class V & $\begin{array}{l}\text { Unskilled workers, including laborers, cleaners, dustmen, etc. } \\
\text { Housewives }\end{array}$ & $\begin{array}{l}\text { Housewife } \\
\text { Social class unsupported }\end{array}$ \\
\hline
\end{tabular}


Table A11 Questions about mother's wellbeing answered by her at age 5 of youngest child

- Do you often have back-ache?

- Do you feel tired most of the time?

- Do you often feel miserable or depressed?

- Do you often have bad headaches?

- Do you often get worried about things?

- Do you usually have great difficulty in falling asleep or staying asleep?

- Do you usually wake unnecessarily early in the morning?

- Do you wear yourself out worrying about your health?

- Do you often get into a violent rage?

- Do people often annoy and irritate you?

- Have you at times had a twitching of the face, head or shoulders?

- Do you often suddenly become scared for no good reason?

- Are you scared to be alone when there are no friends near you?

- Are you easily upset or irritated?

- Are you frightened of going out alone or of meeting people?

- Are you constantly keyed up and jittery?

- Do you suffer from indigestion?

- Do you often suffer from an upset stomach?

- Is your appetite poor?

- Does every little thing get on your nerves and wear you out?

- Does your heart often race like mad?

- Do you often have bad pains in your eyes?

- Are you troubled with rheumatism or fibrositis?

- Have you ever had a nervous breakdown?

- Do you have any other health problems worrying you?

Note: The mother could answer each question with either 'yes' or 'no'. 
Table A12 Examples of questions about mother's attitude toward child rearing and toward other views about life answered by her at age 5 of youngest child

\begin{tabular}{|l|l|l|l|}
\hline $\begin{array}{l}\text { Attitude to maternal } \\
\text { employment }\end{array}$ & Attitude to sex equality & $\begin{array}{l}\text { Attitude to better life } \\
\text { for women }\end{array}$ & Attitude to TV viewing \\
\hline $\begin{array}{l}\text { A wife must sacrifice } \\
\text { her right to go out to } \\
\text { work once she has } \\
\text { children. }\end{array}$ & $\begin{array}{l}\text { Girls are just as capable } \\
\text { of boys to be engineers. }\end{array}$ & $\begin{array}{l}\text { Women need something } \\
\text { more from life than they } \\
\text { can get by just looking } \\
\text { after the home and } \\
\text { children. }\end{array}$ & $\begin{array}{l}\text { Young children who } \\
\text { never see children's TV } \\
\text { miss a lot which is of } \\
\text { value. }\end{array}$ \\
\hline
\end{tabular}

\begin{tabular}{|l|l|l|l|}
\hline $\begin{array}{l}\text { Attitude to hospital } \\
\text { visiting }\end{array}$ & $\begin{array}{l}\text { Authoritarian world } \\
\text { view }\end{array}$ & $\begin{array}{l}\text { Authoritarian child } \\
\text { rearing }\end{array}$ & $\begin{array}{l}\text { Attitude to } \\
\text { child } \\
\text { independence }\end{array}$ \\
\hline $\begin{array}{l}\text { It's best not to visit } \\
\text { children under five in } \\
\text { hospital because it is too } \\
\text { upsetting for the child. }\end{array}$ & $\begin{array}{l}\text { People should be } \\
\text { satisfied with their lot in } \\
\text { this world and not } \\
\text { struggle to get more. }\end{array}$ & $\begin{array}{l}\text { A child should not be } \\
\text { allowed to talk back to } \\
\text { his parents. }\end{array}$ & $\begin{array}{l}\text { A young child must be } \\
\text { allowed to be himself } \\
\text { even if this means going } \\
\text { against his parents' } \\
\text { wishes. }\end{array}$ \\
\hline
\end{tabular}

Note: The mother could answer each statement with 'strongly agree', 'mildly agree', 'cannot say', 'mildly disagree' and 'strongly disagree'. In total 43 statement were given. Statements were positively and negatively framed, resulting in a z-score calculated by the researchers of the British Cohort Study.

Table A13 Miscarriages before the first child (broad definition)

\begin{tabular}{ll}
\hline Nr. miscarriages & Frequencies \\
\hline 0 & 3,683 \\
1 & 352 \\
2 & 63 \\
3 & 11 \\
4 & 3 \\
5 & 2 \\
\hline
\end{tabular}


Table A14 OLS regression of gap on personality traits of child

\begin{tabular}{|c|c|c|c|c|c|c|}
\hline & \multicolumn{2}{|c|}{ OLS without controls } & \multicolumn{2}{|c|}{ OLS with a selection of controls } & \multicolumn{2}{|c|}{ OLS with all controls } \\
\hline & Coeff. & Obs. & Coeff. & Obs. & Coeff. & Obs. \\
\hline Rutter behavioral difficulties & $\begin{array}{c}0.002 \\
(0.009)\end{array}$ & 2841 & $\begin{array}{c}-0.003 \\
(0.009)\end{array}$ & 2829 & $\begin{array}{l}-0.005 \\
(0.011)\end{array}$ & 2220 \\
\hline Self-esteem & $\begin{array}{l}0.018^{*} \\
(0.010)\end{array}$ & 2613 & $\begin{array}{c}0.022 * * \\
(0.010)\end{array}$ & 2605 & $\begin{array}{c}0.025 * * \\
(0.012)\end{array}$ & 1889 \\
\hline Locus of control & $\begin{array}{c}0.021 * * \\
(0.010)\end{array}$ & 2574 & $\begin{array}{c}0.028 * * * \\
(0.010)\end{array}$ & 2566 & $\begin{array}{c}0.034 * * * \\
(0.011)\end{array}$ & 1860 \\
\hline Disorganized & $\begin{array}{c}0.015 \\
(0.010)\end{array}$ & 2537 & $\begin{array}{c}0.005 \\
(0.010)\end{array}$ & 2528 & $\begin{array}{c}0.011 \\
(0.012)\end{array}$ & 1827 \\
\hline Asocial & $\begin{array}{l}-0.013 \\
(0.009)\end{array}$ & 2704 & $\begin{array}{c}-0.018 * * \\
(0.009)\end{array}$ & 2694 & $\begin{array}{c}-0.020^{*} \\
(0.011)\end{array}$ & 1948 \\
\hline Neuroticism & $\begin{array}{c}0.024 * * \\
(0.009)\end{array}$ & 2723 & $\begin{array}{c}0.015 \\
(0.010)\end{array}$ & 2714 & $\begin{array}{c}0.027 * * \\
(0.012)\end{array}$ & 1955 \\
\hline Introversion & $\begin{array}{c}0.008 \\
(0.009)\end{array}$ & 2721 & $\begin{array}{c}0.003 \\
(0.009)\end{array}$ & 2711 & $\begin{array}{l}0.021 * \\
(0.011)\end{array}$ & 1960 \\
\hline
\end{tabular}

Note: Each cell shows the coefficient of a separate OLS regression with the variable indicated in the rows as the dependent variable and birth gap as the independent variable. All dependent variables are standardized to mean zero and standard deviation one. The birth gap is measured in years. The first column shows the results when no controls are added to the regressions. The second column adds controls for number of miscarriages between first and second child (broad), gender, mother's age at delivery of first child, married at time of birth of second child, social class father, social class mother, smoking behavior mother during pregnancy second child, antenatal care during pregnancy of second child. The third columns additionally adds controls for mother's wellbeing at age 5 of second child, second child lives with same parents since birth, and mother's attitudes. See table 1 for definitions of these variables. Standard errors are shown in parentheses. ${ }^{* * *} \mathrm{p}<0.01,{ }^{*} \mathrm{p}<0.05,{ }^{*} \mathrm{p}<0.1$ 
Table A15 First stage regressions of birth gap on miscarriage with control variables displayed

\begin{tabular}{|c|c|c|c|}
\hline & $\begin{array}{l}\text { First stage regression of gap } \\
\text { on miscarriages between the } \\
\text { first and second child }\end{array}$ & $\begin{array}{c}\text { First stage regression of gap on } \\
\text { miscarriages between the first and } \\
\text { second child with a selection of } \\
\text { controls }\end{array}$ & $\begin{array}{l}\text { First stage regression of gap on } \\
\text { miscarriages between the first and } \\
\text { second child with all controls }\end{array}$ \\
\hline Nr. Miscarriages between first and second child (broad) & $\begin{array}{c}1.294 * * * \\
(0.075)\end{array}$ & $\begin{array}{c}1.253 * * * \\
(0.075)\end{array}$ & $\begin{array}{c}1.294 * * * \\
(0.109)\end{array}$ \\
\hline Nr. Miscarriages before the first child (broad) & & $\begin{array}{l}-0.121 \\
(0.075)\end{array}$ & $\begin{array}{c}-0.245^{* *} \\
(0.102)\end{array}$ \\
\hline Gender $(1=$ male $)$ & & $\begin{array}{c}0.013 \\
(0.062)\end{array}$ & $\begin{array}{l}-0.065 \\
(0.078)\end{array}$ \\
\hline Mother's age at delivery of first child (in years) & & $\begin{array}{c}0.026 * * * \\
(0.009)\end{array}$ & $\begin{array}{c}0.014 \\
(0.011)\end{array}$ \\
\hline Married at time of birth of second child ( $1=y e s)$ & & $\begin{array}{c}0.028 \\
(0.211)\end{array}$ & $\begin{array}{l}-0.035 \\
(0.421)\end{array}$ \\
\hline Social class father II & & $\begin{array}{c}0.356^{* *} \\
(0.153)\end{array}$ & $\begin{array}{l}0.327^{*} \\
(0.188)\end{array}$ \\
\hline Social class father III NM & & $\begin{array}{c}0.220 \\
(0.153)\end{array}$ & $\begin{array}{c}0.099 \\
(0.186)\end{array}$ \\
\hline Social class father III M & & $\begin{array}{c}0.330^{* *} \\
(0.138)\end{array}$ & $\begin{array}{c}0.205 \\
(0.172)\end{array}$ \\
\hline Social class father IV & & $\begin{array}{c}0.193 \\
(0.159)\end{array}$ & $\begin{array}{c}0.031 \\
(0.200)\end{array}$ \\
\hline Social class father $\mathrm{V}$ & & $\begin{array}{c}0.027 \\
(0.197)\end{array}$ & $\begin{array}{l}-0.322 \\
(0.274)\end{array}$ \\
\hline Social class father unsupported & & $\begin{array}{l}-0.014 \\
(0.205)\end{array}$ & $\begin{array}{l}-0.066 \\
(0.318)\end{array}$ \\
\hline Social class mother III NM & & $\begin{array}{c}0.047 \\
(0.137)\end{array}$ & $\begin{array}{c}0.014 \\
(0.177)\end{array}$ \\
\hline Social class mother III M & & $\begin{array}{c}0.320 \\
(0.198)\end{array}$ & $\begin{array}{c}0.040 \\
(0.249)\end{array}$ \\
\hline Social class mother IV & & $\begin{array}{c}0.525 * * * \\
(0.150)\end{array}$ & $\begin{array}{c}0.320 \\
(0.197)\end{array}$ \\
\hline Social class mother $\mathrm{V}$ & & $\begin{array}{c}0.218 \\
(0.376)\end{array}$ & $\begin{array}{l}-0.077 \\
(0.499)\end{array}$ \\
\hline
\end{tabular}




\section{Housewives}

Social class mother unsupported

Smoking behavior mother during pregnancy second child (1=smokes)

Antenatal care during pregnancy of second child ( $1=$ yes)

Mother's wellbeing at age 5 of second child

Second child lives with same parents since birth ( $1=$ yes

Mother's attitude to maternal employment

Mother's attitude to sex equality

Mother's attitude to better life for women

Mother's attitude to tv viewing

Mother's attitude to hospital visiting

Mother's authoritarian world view

Mother's authoritarian child rearing

Mother's attitude to child independence

Constant

F-statistic of instrument

Observations

-squared
$-0.196$

$(0.127)$

$-0.317 * *$

(0.148)

$0.142 * *$

$(0.064)$

$0.509 * * *$

(0.085)

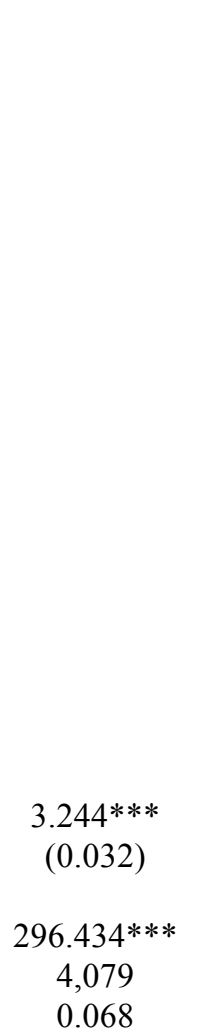

$(0.339)$
$-0.404 * *$

$(0.165)$

$-0.405 * *$

(0.191)

0.113

$(0.081)$

$0.386^{* * *}$

$(0.110)$

$-0.009$

(0.040)

0.179

(0.134)

0.067

(0.044)

0.068

$(0.048)$

0.047

$(0.043)$

-0.070 *

$(0.040)$

-0.083 *

(0.045)

0.000

(0.053)

-0.087 *

(0.052)

$-0.062$

(0.044)

$2.847 * * *$

(0.535)

$280.341 * * *$

$141.957 * * *$

2,337

0.105

Note: Each column shows a regression with birth gap as the dependent variable and miscarriage as the independent variable. See table 1 for definitions of these variables. Standard errors are shown in parentheses. $* * * \mathrm{p}<0.01, * * \mathrm{p}<0.05, * \mathrm{p}<0.1$. 